\title{
POTENTIAL FOR SEED BANK FORMATION OF TWO WEED SPECIES FROM BRAZILIAN AMAZONIA ${ }^{1}$
}

\author{
MOACYR B. DIAS-FILHO ${ }^{2}$
}

\section{ABSTRACT}

The potential for seed bank formation of two perennial weed species, Ipomoea asarifolia (Desr.) Roem. \& Schult. (Convolvulaceae) and Stachytarpheta cayennensis (Rich.) M. Vahl (Verbenaceae), both common in Amazonia, was evaluated in a degraded pasture area in eastern Brazilian Amazonia. Seeds were enclosed in nylon mesh packets and placed at the soil surface or buried at 5 or $10 \mathrm{~cm}$ deep. The number of viable seeds was recorded at $6,10,14$ and 18 months after burial. Results showed that $S$. cayennensis has the ability to form persistent soil seed bank, while I. asarifolia seeds do not build up in the soil seed bank. For $S$. cayennensis and, to some extent, for I. asarifolia, seed survival was highest at greater burial depths.

Key words: Brazil, seed, longevity, Stachytarpheta cayennensis, Ipomoea asarifolia.

\section{RESUMO}

Potencial para a formação de banco de sementes de duas espécies de plantas daninhas da Amazônia brasileira

O potencial para a formação de banco de sementes de duas espécies perenes de plantas daninhas, Ipomoea asarifolia (Desr.) Roem. \& Schult. (Convolvulaceae) e Stachytarpheta cayennensis (Rich.) M. Vahl (Verbenaceae), ambas comuns na Amazônia, foi avaliado em uma área de pastagem degradada na Amazônia oriental brasileira. As sementes foram inseridas em envelopes de tela de nylon e colocadas na superfície do solo ou enterradas a cinco ou $10 \mathrm{~cm}$ de profundidade. $\mathrm{O}$ número de sementes viáveis foi avaliado aos 6, 12, 14 e 18 meses após o início do ensaio. Os resultados mostraram que $S$. cayennensis tem o potencial para formar banco de sementes persistente, enquanto que as sementes de I. asarifolia não apresentam esse potencial. $\mathrm{Em} S$. cayennensis e, de certo modo, em I. asarifolia, a sobrevivência de sementes foi maior nas maiores profundidades.

Palavras chave: Brasil, sementes, longevidade, Stachytarpheta cayennensis, Ipomoea asarifolia .

\section{INTRODUCTION}

Knowledge of the biology of a weed is useful in predicting under what environmental conditions it is most likely to succeed and in devising strategies for its management and control.
Ipomoea asarifolia (Desr.) Roem. \& Schult., a member of the Convolvulaceae, and Stachytarpheta cayennensis (Rich.) M. Vahl, in the Verbenaceae, are important perennial weedy species from pastures and crop areas in Brazil (Lorenzi, 1991), and particularly in Brazilian

\footnotetext{
${ }^{1}$ Received for publication on 20/08/1998 and in the revised form on 19/10/1998.

2 Agronomist, Ph.D., Lab. Ecofisiologia Vegetal, Embrapa Amazônia Oriental, C.P. 48, CEP: 66017-970 Belém/PA, Brazil. Email: moacyr@cpatu.embrapa.br.
} 
Amazonia (Dias Filho, 1990). Although native to tropical America, S. cayennensis also occurs as a weed in Australia (Kleinschmidt \& Johnson, 1987), Hawaii (Haselwood \& Motter, 1983) and India (Nair et al., 1982). In addition, many Ipomoea species are considered as troublesome weeds in warm temperate zones (Elmore et al., 1990).

Little is known about the seed ecology of I. asarifolia and $S$. cayennensis. Previous papers have determined the effect of some environmental and management variables on their germination and emergence (Dias Filho, 1996) and on fecundity of $S$. cayennensis (Dias Filho, 1994). There is no information on seed longevity of these species in the field.

Knowing the survival of seed buried in the field may provide important information on the patterns of persistence and depletion of seeds in the soil seedbank and thus aid in the development of weed management practices (Buhler et al., 1997). Usually, persistent seed banks are well correlated with the success of weeds (Thompson, 1992).

I. asarifolia and $S$. cayennensis have seed masses of $64.31 \pm 1.49 \mathrm{mg}$ and $1.22 \pm 0.04 \mathrm{mg}$ (mean \pm s.e., $\mathrm{n}=52$ ). Seed dispersal of these species takes place all year long and both species seem to have no specialized dispersal mechanisms (agent) (Dias Filho, 1990; 1996). However, they probably benefit from anthropogenic activities for dispersal, being carried in mud on footwear, farm machinery and by stock. A high proportion of $I$. asarifolia seeds is known to possess hard seededness (Dias Filho, 1996).

The objective of this research was to assess the influence of burial depth and duration on seed longevity in the field of I. asarifolia and S. cayennensis.

\section{MATERIAL AND METHODS}

The experiment was established in the beginning of the dry season, on a clayey yellow Latosol (Oxisol) at an abandoned pasture area near Paragominas $\left(3^{\circ} 05^{\prime} \mathrm{S}\right)$, in Eastern Brazilian
Amazonia. The area has an annual rainfall of $1750 \mathrm{~mm}$ and experiences distinct wet (December to June) and dry (July to November) seasons. Freshly collected seed from local field populations were cleaned, dried in the shade at ambient temperature (ca. $27^{\circ} \mathrm{C}$ ) for two days, and stored in paper bags at ambient temperature until the beginning of the experiment, one day later. The initial viability of the seeds, determined in the laboratory by germination test, was $98 \%$ for $I$. asarifolia and $90 \%$ for S. cayennensis. Lots of 100 (S. cayennensis) or 50 (I. asarifolia) seed each were enclosed in small (ca. $15 \mathrm{~cm}^{2}$ for $S$. cayennensis or $30 \mathrm{~cm}^{2}$ for I. asarifolia) nylon mesh packets and placed at the soil surface (slightly covered by soil) or buried at 5 or $10 \mathrm{~cm}$ deep.

Packets were retrieved 6, 10, 14 and 18 months after burial. On each occasion seeds were removed from the packets and the number of viable seeds determined. Seeds were tested for viability if they were whole, undamaged and firm when pressed with the tip of a pair of forceps. Viability of whole I. asarifolia seeds retrieved from the packets was assessed by germinating on soaked rolls of germination paper seeds treated in concentrated sulfuric acid for 20 min to overcome the hard seededness known to occur in this species (Dias Filho, 1996). Seeds were considered viable if they germinated during a seven-day period in a growth chamber with temperature set at $31^{\circ} \mathrm{C}$ (day) and $24^{\circ} \mathrm{C}$ (night), and a photoperiod of $12 \mathrm{~h}$. Viability of $S$. cayennensis was assessed by soaking seed (technically fruits with two seed each) in water for $30 \mathrm{~min}$, slicing off seed coats of both seeds in each fruit at the narrowest seed extremity and put seed in $1 \%$ tetrazolium solution. The seed were left in the dark at $40{ }^{\circ} \mathrm{C}$ for four to five hours. Seeds with embryos that stained pink to red after incubation were considered viable.

The experiment was a split-plot arrangement of a randomized complete block design with burial duration as main plots, burial depth as subplot, and three replications. Data were subjected to response surface analysis. This 
procedure allows a visual interpretation of the response function and interaction between independent variables. Normality of the data was assessed by examining probability plots of residuals. The statistical package STATISTICA for Windows release 5.0 (Statistica..., 1995) was used for all computations of the data.

\section{RESULTS AND DISCUSSION}

I. asarifolia and S. cayennensis showed marked differences in relation to seed longevity in the soil (Figs. 1 and 2). The interaction burial depth $\times$ time was significative for $S$. cayennensis $\left(\mathrm{F}_{1,37}=10.5, \mathrm{P}=0.02\right)$, while no significance could be detected for I. asarifolia $\left(\mathrm{F}_{1,37}=2.7, \mathrm{P}=0.11\right)$. Relative to the initial mean viability of $I$. asarifolia seed (98\% at time 0 ), at the end of the experiment (18 months) a 90,83 or $80 \%$ loss of viability had been experienced, respectively, by the surface, $5 \mathrm{~cm}$ or $10 \mathrm{~cm}$ deep seed. For $S$. cayennensis (90\% at time 0 ) the viability loss was only 55,52 or $24 \%$. From the shape of the survival curve observed for $S$. cayennensis seed (Fig. 1) it could be speculated that this species can build up in the soil seed bank (i.e., is capable of dispersing in time), and that soil cultivation may actually enhance its persistence in agricultural environments by promoting seed burial. On the other hand, the decline observed in the seed survival at the soil surface (Fig. 1) suggests that a fallow period would have a limited success as a control technique for S. cayennensis. Conversely, the observed survival response of I. asarifolia seed (Fig. 2) suggests that eradication of this species could be feasible in a relatively short term if seed production of established plants could be prevented (by periodic mowing, for example) and emerging seedlings controlled. The lack of a specialized long distance dispersion mode known to exist in I. asarifolia (Dias Filho, 1990) could further help in the success of an eradication program of this species from agricultural areas. The present data also suggest that, unlike $S$. cayennensis, a fallow period may be successful as a control technique for I. asarifolia since it seems to be potentially incapable of forming a persistent seed bank.

The methodology used did not allow for a positive estimation of the exact proportion of seed lost through germination in situ, as opposed to the one from seed that died without germinating. However, traces of seedlings could be observed in the burial packets at all planting depths and throughout all evaluation dates for I. asarifolia (data not shown). This observation suggests that germination may play an important role in the decline of soil seed bank for this species. No traces of seedlings could be observed in the burial packets of S. cayennensis. However, the smaller seedling size of this species probably makes seedling detection very difficult. A previous work has found a positive photoblastic nature of $S$. cayennensis seeds and shown that seed burial (up to $10 \mathrm{~cm}$ ) has no effect on emergence of $I$. asarifolia, while $S$. cayennensis is negatively affected (Dias Filho, 1996).

For $S$. cayennensis and, to some extent, for I. asarifolia, the shape of the curve fitted to the survival data (Figs. 1 and 2) suggests that the decline in viability was relatively faster for seeds at the soil surface. This is probably caused by the more variable conditions (e.g., great diurnal fluctuations in temperature and humidity) that may have been experienced by seed at the soil surface; this environment could help overcome the hard-seededness known to exist in I. asarifolia, increasing germination and thus decreasing seed survival. In addition, as $S$. cayennensis seed are known to have a positive photoblastic behavior (Dias Filho, 1996), seed at the soil surface would also be more prone to germination than buried seed. As a consequence, for both species, a relatively higher proportion of seed was probably lost via germination at the surface than at 5 or 10 $\mathrm{cm}$ deep. This result supports the general findings that the deeper the seed burial the longer the persistence in the seed bank (Bourdôt \& Hurrell 1992, Bridgemohan et al. 1991; Eberlein 1987; Ralphs \& Cronin 1987; Schwerzel 1976). 


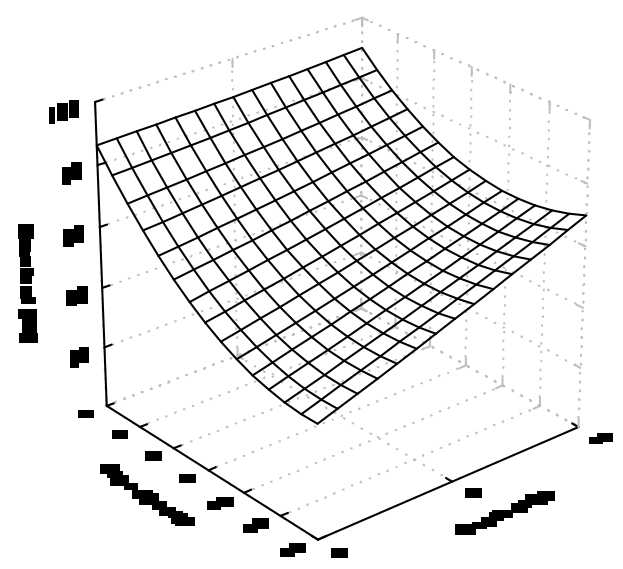

FIGURE 1. Survival response of Stachytarpheta cayennensis seeds to time and burial depth in the field. The regression equation is: $\mathrm{S}=86.37-5.68 \mathrm{~T}+0.16 \mathrm{~T}^{2}+0.15 \mathrm{D}+0.02 \mathrm{D}^{2}+0.16 \mathrm{TD}$, where $\mathrm{S}=$ survival percentage, $\mathrm{T}=$ time (months), $\mathrm{D}=$ burial depth $(\mathrm{cm}) \cdot \mathrm{r}^{2}=0.83$

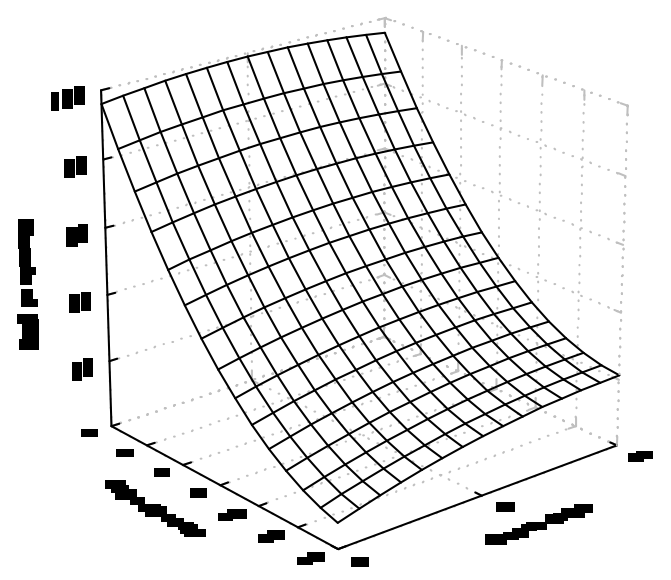

FIGURE 2. Survival response of Ipomoea asarifolia seeds to time and burial depth in the field. The regression equation is: $\mathrm{S}=96.06-8.81 \mathrm{~T}+0.217 \mathrm{~T}^{2}+1.19 \mathrm{D}-0.12 \mathrm{D}^{2}+0.08 \mathrm{TD}$, where $\mathrm{S}=$ survival percentage, $\mathrm{T}=$ time (months), $\mathrm{D}=$ burial depth $(\mathrm{cm}) . \mathrm{r}^{2}=0.95$. 
The results showed that seeds of $S$. cayennensis and $I$. asarifolia have marked differences in their ecological longevity, i.e., the mean time that seeds remain viable in the soil under the influence of the natural environment (Vázquez-Yanes \& Orozco-Segovia, 1996). S. cayennensis has a great potential for forming persistent soil seed bank while I. asarifolia has proportionally a very limited capacity to persist in the soil seed bank.

Based on their seed bank characteristics, it could be speculated that recruitment of seedlings from the soil seed bank would be an important invasion strategy of $S$. cayennensis, while $I$. asarifolia might primarily benefit from seed rain.

\section{ACKNOWLEDGEMENTS}

To Miguel Simão Neto and José Luiz Covre for the assistance in the field.

\section{REFERENCES}

BOURDÔT, G.W.; HURRELL, G.A. Aspects of the ecology of Stipa neesiana Trin. \& Rupr. seeds. N. Z. J. Agric Res., v.35, p.101-108, 1992.

BRIDGEMOHAN, P.; BRATHWAITE, R.A.I.; MCDAVID, C.R. Seed survival and patterns of seedling emergence studies of Rottboellia cochinchinensis (Lour.) W.D. Clayton in cultivated soils. Weed Res., v.31, p.265-272, 1991.

BUHLER,D.D.; HARTZLER, R.G.; FORCELLA, F. Implications of weed seedbank dynamics to weed management. Weed Sci., v.45, p.329-336, 1997.

DIAS FILHO, M.B. Plantas invasoras em pastagens cultivadas da Amazônia: estratégias de manejo e controle. Belém: Embrapa-CPATU, 1990. 103p. (EmbrapaCPATU. Documentos, 52).
DIAS FILHO, M.B. How is fecundity affected by mowing in the tropical weed Stachytarpheta cayennensis (Verbenaceae)? Pesqui. Agropecu. Bras., v.29, p.1675-1679, 1994.

DIAS FILHO, M.B. Germination and emergence of Stachytarpheta cayennensis and Ipomoea asarifolia. Planta Daninha, v.14, p.118-126, 1996.

EBERLEIN, C.V. Germination of Sorghum almum seeds and longevity in soil. Weed Sci., v.35, p.796-801, 1987.

ELMORE, C.D; HURST, H.R.; AUSTIN, D.F. Biology and control of morningglories (Ipomoea spp.). Rev. of Weed Sci., v.5, p.83-114, 1990.

HASELWOOD, E.L.; MOTTER, G.G. Handbook of Hawaiian weeds. 2nd. ed. Honolulu: University of Hawaii Press. 1983. 491p.

KLEINSCHMIDT, H.E.; JOHNSON, R.W. Weeds of Queensland. Brisbane: Queensland Department of Primary Industries, 1987. 469p.

LORENZI, H. Plantas daninhas do Brasil: terrestres, aquáticas, parasitas, tóxicas e medicinais. 2 ed. Nova Odessa: Plantarum, 1991. 440p.

NAIR, N.C.; MOHANAN, C.N. \& SREEKUMAR, P.V. Stachytarpheta cayennensis (L. C. Rich) Schau.- A new record for India and with a key to the Indian species. Journal of Bombay Natural History Society, v.79, p.230232, 1982.

RALPHS, M.H.; CRONIN, E.H. Locoweed seed in soil: density, longevity, germination, and viability. Weed Science, v.35, p.792795, 1987. 
SCHWERZEL, P.J. The effect of depth of burial in soil on the survival of some common Rhodesian weed seeds. Rhod. Agric. J., v.73, p.97-99, 1976.

STATISTICA for Windows. General conventions and statistics. Tulsa: StatSoft, Inc., 1995. v.1, 717p.

THOMPSON, K. The functional ecology of seed banks. In: FENNER, M. (Ed.). Seeds: the ecology of regeneration in plant communities. Southampton: CAB International, 1992. p.231-218.

VÁZQUEZ-YANES，C.; OROZCO-SEGOVIA, A. Physiological ecology of seed dormancy and longevity. In: MULKEY, S.S.; CHAZDON, R.L. (Eds.). Tropical Forest Plat Ecophysiology. New York: Chapman \& Hall, 1996. p.535-558. 